\title{
Origins of the Professional Musical and Choreographic Art of Buryatia
}

\author{
Olga Iu. Kolpetskaia* \\ Krasnoyarsk State Institute of Arts \\ 22 Lenin Str., Krasnoyarsk, 660049, Russia
}

Received 15.01.2017, received in revised form 24.07.2017, accepted 08.08.2017

The roots of professional musical and choreographic art of Buryatia go back to deep past, keeping its connection with the folklore and cult practices of the ethnos and its world outlook. With some elements adopted from folk games, religious and household rituals, modern producers manage to re-create the original dance with its distinctive ethnic colour, drawing various plastic patterns and combinations in the traditional art of the ethnos. Many choreographic moves are typical for the old Buryat pattern. Their semantics is included into the structure of the national world outlook, connected with the shamanist and Buddhist vision of the world.

Keywords: Buryat folklore, choreographic traditions, shamanism, yokhor roundelay dance, Buddhist miracle play Tsam, inclusivity.

DOI: 10.17516/1997-1370-0126.

Research area: culturology, art criticism.

Professional musical and choreographic art of Buryatia has been forming throughout the $20^{\text {th }}$ century under the influence of different traditions of the original national culture. At the same time, it has adopted the rich experience of West European and Russian classics, as well as modern music and choreographic achievements. Ballets by such composers as D. Aiusheev, S. Riauzov, B. Mayzel, L. Knipper, B. Iampilov, Zh. Batuev, A. Andreev, Iu. Irdyneev in creative cooperation with choreographers M. Arsenyev, I. Moiseev, M. Zaslavsky, M. Mnatsakanian, A. Batubaeva, O. Ignatyev prove the significance of this art in the Republic. It is not a coincidence that the production and composition practice, national specificity of music and choreography provide wide and rich research material.

As for choreographic traditions, Buryat folklore demonstrates them in thousands of ways. The analysis of Buryat dance combined with other elements of culture finds some problems in the ethnic history of the nation, its economic activity, world outlook and everyday life specificity.

Unfortunately, due to the peculiarities of choreography, a great part of the national dance treasury has been lost forever, and the part that still lives in the people's life is stylized beyond recognition, losing its original features. Some invaluable help was received from published and unpublished materials of field expeditions to

(C) Siberian Federal University. All rights reserved

* Corresponding author E-mail address: colpa69@mail.ru 
Buryat provinces, documents and manuscripts kept at the Central State Archive (CSA) of Buryatia, the Manuscript Department of the Institute for Mongolian, Buddhist and Tibetan Studies of the Siberian Branch of the RAS, multiple works on ethnology as well as data provided by philosophy, culture studies, social science and history.

The first written evidence of Siberian folk dance dates back to the 17-18 ${ }^{\text {th }}$ centuries (Zuev, 1947; Ides, Brand, 1967). These researches describe some hunting dances ("Blackcock dance", "Bear saltation"), indissolubly connected with their origin of a magical ritual. They appeared when the ancestors of today's Buryats were the so-called "forest people" engaged in hunting, fishing, gathering herbs and edible plants. As noticed by O. Buksikova, "opinions of modern researchers on the "genetic roots" of the dance match in two main points. The first one is that the dance is a part of emotional experience expressed in plastic movements used to shape and express the sensation of belonging to the surrounding world. The second is that the dance appeared in the ancient period of human history, performed to the rhythm of primitive drums, had a ritual and symbolic meaning even back then" (Buksikova, 2009: 49). Dancers imitated behaviour of animals and hunters they observed in real life. The magical ritual preceding hunting had a certain meaning: people did not just prepare to attack the object of their hunt; they performed the act of hunting in an advanced, look-ahead way, pre-determining the future success (that is where the "training dance" term by V. Romm originates from (Romm, 1998)).

In his work "Early forms of religion", based on the social purpose of magical rituals, S. Tokarev outlines the following classes of magic: malicious, military, sexual, hunting, meteorological, and other "secondary" ones. On the basis of psychological concepts, the researcher also suggests the classification of types of magic: contact, cathartic, verbal, initiating, imitating, apotropaic (Tokarev, 1990: 426-501). However, he remarks: "...It would be wrong to expect the magical acts to be strictly divided into classes and types of any classification system. In many cases magical rituals demonstrate a combination of two, three or even more different principles. Such rituals belong to combined types" (Tokarev, 1990: 432). Based on the classification created by $\mathrm{S}$. Tokarev, each ritual is defined twice, by belonging to a certain class and type of magic: "It is convenient to do with a special conventional code in the form of a fraction, where the nominator indicates the class, and the denominator shows the type of the magical ritual" (Tokarev, 1990: 438). Thus, the dances described above originated from the ritual which can be described as hunting/imitating.

One of the most ancient dances of Buryatia are the military fight-dances, a sort of "military" magic. This type may be classified both as "contact", "imitating" or "initiating" magic (military/contact+imitating+initiating).

It was extremely meaningful that in the past all members of the community participated in such rituals. First of all, it brought people to learning the laws of the community, getting some practical skills, developing common strategy and tactics, especially if the rituals were associated with some labour processes or military campaigns. People learned the entire ritual and its separate elements, mastered the choreographic elements and their sequence since the earliest age. "Psychologically, the massive theatrical performance aided development of the "collective conscience" as a single entity" (Gerasimova, 1988: 53), while the synchronized hypnotizing rhythmic moves created a specific “psychic medium” (Gerasimova, 1988: 53).

According to one of the hypotheses (as explained by V. Romm (Romm, 1998)), dance had 
appeared long before the human learned how to speak. In the ancient types, mimic, gestures and moves served as a substitute for speech. For this reason, rhythmically organized dancing moves acted as an important means of communication. Even after people had mastered speech, “...the system of totemic taboos became widely spread: many things were forbidden to say out loud $\langle\ldots>$. All this maintained the significance $\langle\ldots\rangle$ of training-dances" (Romm, 1998: 115).

In the ancient times, various folklore genres were not differentiated from the syncretic whole. They were naturally included into the common outlook of the cosmos, nature, and society, concentrating practical experience, real knowledge, forming a single whole with mythology, functioning together with it, working as an integral part of rituals, labour processes, social and everyday relations. In such conditions, any folkloric text is functionally universal and concrete at the same time for being tightly "bound" to a certain repeated ritual situation.

With the development of new social relations and transition to the cattle breeding stage, hunting and military dances began to lose their magical meaning. They are now performed during naadanakh holiday as a sort of entertainment, at the same time preserving the traditions going back to the earliest days of Buryat culture. Thus, the "Wood grouse dance" found not only in Buryat, but also Evenki, Mongolian and Bashkir cultures, i.e. the three main branches of Altaic language family: Tungus, Turkic, and Mongolian, became a comic performance. It is described in works by V. Naidakova (Naidakova, 1985), T. Gergesova (Gergesova, 1974), D. Dugarov (Dugarov, 1991). "The dancers make a roundelay circle, with one girl (female blackcock) and two lads (male blackcocks) standing in the centre. All together, they hunker down and imitate the spring call of the birds. The "males" huff and puff, sprawl out, wave their hands as if they were wings, lift the bottoms of their coats imitating open wings and fanned tails of the birds $\langle\ldots$.. In the last lines of each verse, the lads come together, and, making the "kish kish kish" sound, push each other with their shoulders, trying to knock each other down. The one who falls leaves the circle and chooses a new "grouse" from the roundelay and takes his place" (Dugarov, Kunitsyn, 1997: 373-374).

As we see from the description, each dancer played a certain role, creating a sort of performance, which is the basic distinctive feature of theatrical act. Lightness, rhythm of the dancers' moves, the precision in reproduction of birds' behaviour pleased the spectators. Their reaction stimulated the dancers, pushing them to making up new and new moves. Therefore, there appears another important factor, which is the contact of actors and spectators.

Buryat folklore tradition includes a large number of dance-games, pantomimegames. Those are "The bear game", "Hide the mitten" described in the book by T. Gergesova (Gergesova, 1974), "Hide the gold" (a specific analogue of the Russian game "Golden ring, come out at the porch"), "Find the awl and scissors", "Tame the wild horse", comic game "The mocking bird", "Wit contest" studied thoroughly by V. Naidakova (Naidakova, 1985), "Kerchief”, "White tree", "Surkharban" holiday games analysed in works by I. Tugutov (Tugutov, 1989), A.-D. Shagdaron and B.-D. Ochirov (Shagdaron, Ochirov, 1909).

Buryat games and rituals everyone could take part in are a real "theatre-for-itself", just like the whole life of the community is "life-foritself". An individual does not stand out from the group he belongs to, but merges with it as a part merges with a whole. Let us remark that the division between actors and spectators is conventional, since any spectator may become a performer at any moment. 
The history of Buryat folklore and choreographic traditions is closely intertwined with the religious and mythological outlook of the nation and shamanism in particular: "Shamanism may be defined as an aggregate of traditions where those who practice it voluntarily enter the altered state of mind and feel themselves and their spirit travelling in other media, interacting with other entities for the interests of their community" (Mikhailov, 1987: 21).

The shaman Universe consists of three layers, i.e. the upper, the middle and the lower worlds. The shamans are convinced that all the three worlds are united with the world axis, Axis mundi. As we know, in different cultural traditions and myths the axis may take various forms. The first one is the "cosmic mountain" in the middle of the Earth. The second one is the "world pillar", the symbol of life, wealth and holy renaissance. The third one is the "world tree".

In the traditional Buryat concept "the world (shaman's) tree" and the "world mountain" could coincide. For example, the trees growing on the holy mountain, and the mountain itself when trees were specially delivered to it for some ritual acts were considered to be the objects for worship and respect.

The shaman's Universe is full of deities and spirits influencing the human life. The Buryat pantheon is a hierarchy where the highest position is occupied by Khukhe Munkhe Tengri, the Eternal Blue Skies. In accordance with the ancient beliefs of the Buryats, in the skies there is celestial life similar to the mundane one. The skies are inhabited by kind and evil, light and dark celestial beings (tengriia). All of them are eternal, for they were born by the Skies, act by its will and for its purposes. The king of the underworld is the notorious Erlen-khan (Erlikkhan), who has lots of scriveners, assistants, and hunters for human souls.
The middle world, the closest one to people, is the place where shaman can travel easily, overcoming any obstacle. Having returned, he shares his knowledge of hunting, weather or dangers, accompanying the story with mimic and gestures.

Shamans stand out from the group for with their observance, emotionality, expressiveness, ability for hypnosis and self-hypnosis, improvisation, acting and musical skills: "Shaman rituals can attract great audience even with one shaman's actions (improvisations depend on the variety of situations...)" (Dugarov, 1991: 147). V. Inkizhinov noticed "true dramaturgy, creation of lyrics and immediate performance by the author, the actor of the religious theatre" in shaman's rituals (Inkizhinov, 1929: 51).

Any shamanistic ritual followed a certain storyline and had a well-arranged composition: the sequence of actions included an essential trip of the shaman to the world of spirits and his return to the human world. This is where the idea of reversibility, noticed by multiple researchers in shamanistic rituals, comes from. An important condition of the shaman's action is the presence of a prepared spectator, knowing the meaning of each gesture, move, or sign. Those present at the ritual understood, that if at the beginning the shaman shifted from one foot to another, it symbolized his hard first steps into the other worlds. Another typical move of the shaman was jumping on two feet: it meant riding on a horse. The shaman could imitate his fight with evil spirits. The role of the audience was to sympathise the shaman in all the challenges of his journey.

Acting was extremely important in the whole ritual: the shaman roleplayed everyone he met during his cosmic journey. Though physically being among people, for all the spectators the shaman acted in another world inaccessible to them, in a different sphere; for this reason, during 
the ritual no one could interact with him. The shaman's "performance arsenal" also included calls and songs for the gods and spirits, saltation, playing drum (the shaman's drum was perceived as a generalized acoustic symbol of the world, in the people's consciousness associated with a supernatural source of sound), clinking sounds of metal and ivory pendants on his costume, illusions, hypnosis, ventriloquism, and circus tricks.

Therefore, a shamanistic ritual was a real performance, a bright show of one actor. The shaman's saltation was a solo improvisation, the climax of which was a wild, uncontrolled flow of the wildest moves the human body is capable of. It is extremely hard to find any choreographic combinations in the shaman's saltation. It is composed by each and every shaman for every individual ritual and depends on the storyline composed by the shaman himself.

However, shaman's performance cannot be considered to be just a theatrical act, for the shaman, first of all, serves as a minister of religion and uses theatrical or even circus techniques to enhance the expression and strengthen the religious faith of the people: "And since it does not appear strange to us that the ministers of the church (such as, for instance, vagrant dwarfs) played a great role in the development of the Medieval theatre, since we include some religious pieces, such as The Play of Daniel, into the history of Russian theatre, we should give the shamans a certain place in the theatre evolution as well..." (Avdeev, 1959: 168).

The descriptions of shamanistic rituals present in modern literature prove that the dancing skills of the "cosmic travellers" were quite advanced.

In the diversity of theatrical and choreographic traditions of the Buryats special interest is caused by yokhor, often mentioned in the national epos. Yokhor is a syncretic ancient kind of a folk dance, which can be compared, for example, with Slavic roundelay dances. The term yokhor as a name for the game and its main chorus word is also common for Evenki, Dolgans, Yakuts. D. Dugarov suggests that the word yokhor meaning "up", "ascend" was adopted from Old Uygur language (Dugarov, 1991). Yokhor is the only roundelay dance found in the culture of Mongolian speaking nations. In the subject-locative code of yokhor, the centre, marked with various attributes, such as a bonfire, a tethering post, a pole, a mountain, a tree, some food, a fireplace, or a cart, bears a sacral meaning.

The developed roundelay dance tradition of the Buryats can be found both in Russian and foreign researches written in the first half of the $18^{\text {th }}$ century. The existence of roundelays in earlier periods is proven by folkloric tales, ethnographic data and archaeological findings.

Thus, the ancient archaeological findings in the Transbaikal Region, the petroglyphs, pictures of animals and people standing in a circle, stamped and drawn with ochre, point at the cult locations where the archaic rituals took place. A. Okladnikov and V. Zaporozhskaia suggest that the pictures of people holding each other by the elbows depict a roundelay dance similar to yokhor (Okladnikov, Zaporozhskaia, 1970).

The collected field research materials and literature suggest that the ancient ritual of the white shaman initiation always ended in a roundelay around the bonfire. Description of the final part of the ritual can be found in "Old faith of the Buryat people" by B.E. Petri: "The evening is coming. The audience is slowly dissolving. Bonfires are burnt here and there. Young people start dancing roundelays and singing songs. The last rays of the sunset are fading out; the singing is loud and confident. Young lads and girls move smoothly and rhythmically, in tight circles. The joy that has been reserved all day long finally bursts out. If you feel like dancing, then go and 
dance! Lots of invisible deities have come to the initiation party. They tie their invisible horses to the tethering post and dance with the youth. If they dance badly, the gods will feel bored and go home sad; that should not happen. The young people dance until morning light, refreshing with a cup of tarasun drink. They have to dance like this for nine days" (Dugarov, 1991: 64).

Later, the final part of the shaman initiation ritual, the roundelay dance, lost its connection with the ritual and began being performed separately.

According to the informers, in the ancient times yokhor was begun by eight, or, according to other sources, by nine young lads (the number of children of Khukhedey Mergen, the Thunder God). As D. Dugarov remarks, the Buryat myth claims that they had been sent to the Earth with the mission to bring farriery to people and to ascend back to the skies after it is complete. All this (including the quotation from B.E. Petri) seems to prove that the Buryats had never had a special tradition of a dance started by elderly people. However, it is known that in different rituals a certain meaning was borne by the age group that performed yokhor dance. D. Nikolaeva believes that the roundelay performance by elderly people is associated with a "connection between the ancestors and the successors, the deceased and the living members of the community". In the wedding ritual, it is associated with the "transfer of an individual from one social position to another", with the union of "two marrying families" (Nikolaeva, 1998: 65). The opinion of D. Nikolaeva is proven by the leading Buryat folklore researchers. Thus,

I. Tugutov writes that "starting a dance without old men and women is a sin" (Tugutov, 1989: 83). On the other hand, I. Manzhigeev, who engaged in studying the Yerdynsky game, the calendar ritual of the Western Buryats, remarked that yokhor is belongs exclusively to the youth, and it is improper for older people to participate" (hereon: (Manzhigeev, 1985: 114)).

In his work "Historical roots of white shamanism" D. Dugarov presents a description of Unga yokhor (Dugarov, 1991).

Every ulus had a special place for dancing, usually located outside the village, in the steppe. The dancers stood around the bonfire, and, holding hands, slowly moved clockwise, rocking from side to side. Dancing counterclockwise was strictly forbidden, since it was believed that only evil spirits can move in that direction. The arms of the dancers were down and free, hands holding the hands of the neighbours. The roundelay was started from the left leg, foot across. The songs were sung in time of the move. Then the singers would change the tune for a faster one.

The second part is the longest. The dancers held their hands over their waists, pressing their bent elbows to the sides, making the circle smaller; the dancers stood closer to each other, the feet stamping stronger with the beat. As a rule, the songs of the second part were sung by one soloist, a better vocalist.

As soon as any of the dancers cried out, "Zai, debkhereebdi!" ("Let's jump!"), the people narrowed the circle even more, standing closer shoulder to shoulder, and started moving very fast. In some districts of the republic this part of the dance is known as "shangalgyn duun" ("the fast dance song"). The tune is simpler, with one sound corresponding to each syllable of the lyrics. Sometimes, before the fastest part of the yokhor, the dancers said: "Zai, khatarae!" ("Let's trot!") Obviously, these words used to bear magical meaning, and the dance was based on the imitation of a trotting animal (lynx, horse, moose). Here we need to remember that in shamanistic rituals "the drum and horse canes had similar symbolic meanings; they represented a horse the shaman rides around the earth, goes up to the sky and descends to the dungeon of 
Erlen-khan” (Dugarov, Kunitsyn, 1997: 367). Possibly, the dance of the gathered people helped the shaman travel around the Universe. There are reasons to suppose that yokhor was performed during shamanistic rituals.

The roundelay dance played a special role in the Buryat wedding ceremony. As remarked by D. Nikolaeva (Nikolaeva, 1998), it performed various functions:

1) dancing yokhor in a house around some food (or fireplace as the heart of the house) is a last treat for the parents and relatives of the bride, some parting words and wishes for the young wife;

2) dancing in the yard around the bonfire (farther from the centre) is preparation for changing the girl's status;

3) dancing yokhor in the street around the bonfire (the street symbolizes the borderline between the "domestic" and "strange", "outside" world) represents the bride's entrance into the new family.

Therefore, yokhor has always been an essential element of Buryat national rituals (shamanistic, wedding, calendar rituals, national and family celebrations). In different districts of the republic there are their own, local roundelay dances (Alaro-Unga, Ekhirit-Bulagat, Idinsky, Tunkinsky, Zakamensky, Baikal-Kudarinsky, Barguzin and East Buryat), with the cultural and ethnic specificity manifesting itself in the structure, form and character of moves.

Observing the roundelay dance in some districts of the republic, D. Dugarov paid attention to the tradition of dancing yokhor with slow acceleration towards the final. The researcher remarks: "The tendency for gradual acceleration from slow, quiet beginning to fast, harsh jumps is a common for all the districts where roundelays exist" (Dugarov, 1991: 89). However, we do not agree with the author, since such tradition is not found in the yokhor of Zakamensky Buryats, where it is present in two variations: the fast one referred to as ayduusay, yagaruukhay, and the slow one, undehen yookhor. This data was found during the field research of the author of the present article in Zakamensky district of Buryatia $(1995,1996)$.

In Zakamensky district, roundelay is performed according to the contrast tempo interchange principle: slow - fast - slow - fast ...

Some of the researchers claim that the dance moves mostly depend on the yokhor lyrics and even on one word in the chorus cried out by the dancers before it starts. The lyrics of the fast and the slow yokhor verses can be the same, while the chorus is always based on the key words determining the types of the dancing moves.

In the earlier period, the words accompanying the dance did not bear any meaning. However, they were traditional and known to all the performers. Repeating the same songs day by day, year by year, the dancers brought performance to automatism. The dance mesmerized people with its rhythm so much that they started omitting words in every line. D. Dugarov writes: "When I heard the real Tunkinsky yokhor for the first time, I was astonished by the eurhythmy of the dancers, but after a while I realized that I did not any longer understand what they sang. It turned out that they omitted the first words of each line, just did not sing them anymore, turning the song into something absurd" (Dugarov, 1991: 108).

The distinctive feature of the slow yokhor is the richness of melody ornament and complicated rhythm, which, however, does not break the uniformity of the dancing step. There are very few records of it. Mostly they only show the melodic formula without the rhythmic and intonational flourish indicating the vocal skill of the singer and his improvisation talent.

The fast yokhor songs are distinguished with their stricter metric organization, uniform 
accents with the great diversity of melodic and modal variations.

The question of yokhor origin still needs some thorough studies, since, according to D. Dugarov, this special form of folk choreography, being an important element of the shamanistic ritual complex, could be adopted from Indo-Iran and Indo-European tribes. However, there are few proofs of this hypothesis.

Along with yokhor, there is another dance extremely popular in the republic: ner'elge (the name of the dance originated from the word ner'e, "growl", addressing Aya, the thunder god), the roundelay of Eastern (Agin) Buryats. It has not been practised since the early $20^{\text {th }}$ century. Today we can study this dance only from the ethnographic data. We know that ner'elge used to be performed at Eastern Buryat weddings by the bonfire - tuudzhi, as well as during shamanistic rituals: "With the dance and its chorus lyrics, shamans ascended to the sky, or sent their offerings, prayers of their fellow tribesmen, souls of the dead to heaven" (Dugarov, 1991: 189).

According to the data, this dance was performed by young people, who divided into two groups and stood shoulder to shoulder, facing each other (or "wall-to-wall" as an option), holding hands behind their backs, and rocked from side to side.

Each of the three verses of this roundelay is devoted to a certain sphere of the world: to the skies (the upper world), to the Earth (the middle world), and to water (the underworld). These spheres are symbolically represented by their inhabitants: a bird (eagle), an animal (deer) and a fish. All the three worlds are united by the shaman tree, which provides communication between the worlds. Perhaps, the dance was originally performed around the tree which presented the "Axis mundi".

The shamanistic worldview of the Buryats started going through some significant changes in the early $17^{\text {th }}$ century. They were caused by the appearance of Buddhism that gradually conquered the Baikal and Transbaikal Regions. The religion was spread not only from Tibet through the missionary lamas, but also through Mongolia, where the religion had contacted with the local cults and beliefs. This Tibet-Mongolian variant of Buddhism is normally referred to as Lamaism.

The archetypical concepts of the rituals that appeared in the pre-Buddhist period can be found in tsam mystery play. The multiple participants of this religious action wore big masks and roleplayed the fight of gods from the Buddhist pantheon.

In Tibet language, the word 'cham has two meanings. As a verb, it can be translated both as "to dance" and "arrive to concord" (in the latter case, it can be spelt as 'cham, or bcam as an option). The noun 'cham pa, therefore, means both "dance" and "concordance". Interestingly, in the meaning "dance", the word 'cham can be only applied to religious celebrations and ceremonies. Speaking of secular dance performances, the word gar is normally used. In Russian Oriental Studies, the word 'cham is transcribed as tsam in Khalkha tradition: first of all, Russian researchers studied this mystery play in the Buryat-Mongolian areal; secondly, this term is most frequently used by the people that profess Buddhism in the territory of Russia (Kolpetskaia, 2011).

The homeland of tsam is Tibet. It is claimed to have been created by Padmasambhava, a Buddhist master who lived in the $8^{\text {th }}$ century. According to a Tibetan legend, while Padmasambhava was building Samye Monastery, the spirits of the land did everything to prevent his work. Wearing the costume of his protector deity, the Master performed a sacred dance and appeased the spirits, forcing them to promise that they would never do any harm to the monastery. 
Tsam was initially performed in a temple or in a monastery yard, where it could be observed only by initiated people. Later everyone was allowed to watch the dance. Let us remark that the storyline of tsam could be only understood by those who knew the sacred meaning of the movements, gestures and spells. Some Lamaist temples still keep old Tibetan books of tsam, written with special formulae and symbols that cannot be found in any European-Tibetan dictionaries. It is only known that the dancing moves and their sequence were passed on by the ministers of religion from one generation to another.

Every Lamaist temple specialized only in one variation of the mystery play and worked to improve it. It was performed year after year, and the actor lamas used the same masks and properties. Thus, Hambin temple of Buryatia specialized in the dokshit tsam (tsam of the severe, vicious keepers of the Buddhist faith). The characters of the play appeared before the audience wearing intimidating bright masks. The tsam masks are quite heavy (the weight of one mask could reach 30 kilograms). Each temple had its own costumes and stage properties; the lamas kept and preserved them. If any masks wore out, they would be repaired or replaced with new ones, with all the rituals performed.

The data of tsam played at Hambin temple (residence of Bandido-Khambo-lamas) are presented in the book "Buddhist tsam mystery play in Buryatia" by V.Ts. Naidakova (Naidakova, 1997). The data was provided by lamas and elderly people, who witnessed the mystery play performance in the 1920s. Moreover, a detailed description of the dokshit $t$ sam with the analysis of its evolution can be found in the ethnographic research by B.P. Sal'mont, a unique source of information on the culture of the nation "Materials for studying Buryat-Mongolian art (songs, music, dance)" (Sal'mont, 1928). This research is kept at the Manuscript Department of the Institute for Mongolian, Buddhist and Tibetan Studies of the Siberian Branch of the RAS and, unfortunately, has not been published yet.

It is a known fact that in July 1926 Boris Petrovich Sal'mont was present not only at some tsam rehearsals, but also participated in the mystery play as a spectator at Hambin temple in Buryatia. In his research, he described three parts of the mystery play. The criterion for division was the time of the day: "Part 1: a night prayer, a ceremonial service and the dance of one of the shanaks (the observer lama); Part 2 (morning and afternoon) - a pantomime ballet accompanied by choir and orchestra, and Part 3 - the oblation (evening)" (Sal'mont, 1928: 185). Referring to the memories of the spectators and performers of the tsam, V.Ts. Naidakova remarks that the ritual masks dance could only start after the closed part of the service, where the laity are not allowed. This part of the ritual was conducted inside the temple in the presence of the selected ministers of religion, privy to the mystery play procedure. The closed ceremony was led by a specially trained chambon lama. He was the one who carried out the Sor consecration ritual. The Sor is one of the main attributes of the dokshites' tsam: it symbolized the offering which helped overturn the enemies of the faith and clean the karma. The Sor was a three-headed pyramid made of dough, with a top finished with an object reminding of a human skull. The scarlet edges of the pyramid symbolized flicker flames. Moreover, the gelyunlama, who assisted the chambon during the night prayer, poured some blood from bala (a vessel made of a human skull) into the deber bowl. After that the chambon would step away and pour the blood from the deber into a sheep stomach, tie it up and place it into the Linka. The Linka is a dough human figure, the embodiment of all the sins and enemies of the faith. Therefore, the ritual 
figure contained some dangerous enchanted content.

According to the observations of B.P. Sal'mont, the mystery involved 78 people wearing costumes and 16 more people who assisted the ceremony. Moreover, the orchestra consisted of 49 musicians and the choir counted over 50 people. However, in the conclusion the author provides different data on the number of the tsam participants: 50 people of the orchestra, 100-150 people of the choir and 77 dancers.

The seating of the spectators in the amphitheatre manner reminded of a Greek theatre. Before the main temple in the centre of the square there was a table with a silk tester over it. Around the tester, several concentric circles were drawn with chalk or lime, marking the dancing area for the mask wearing actors. Traditionally, the tsam would begin with the presentation of the Sor and the Linka, placed on the table under the tester. Near the external circle, the orchestra was seated. The dancers would come out to the dancing area to the sounds of cult musical instruments.

In her tsam research, V.Ts. Naidakova outlines three groups of the mystery play characters (Naidakova, 1997). The first one is the sinister dokshit masks, the genius protectors of Buddhism. Their masks are painted blue, green, red, and dark yellow. The dokshit faces are drawn with the grimaces of fury, anger, indignation. Each of them has the third eye, urna, the allseeing eye in the forehead. The sinister deities are supposed to kill the heretics and enemies of religion, to inspire fear and horror in the audience. Each dokshit is accompanied with his escort.

Choydzhil (Tib. Choydzhal, Choychzhal, Ancient Uygur Erlik, Ancient Indian Yama), the main character of the tsam, the king of the underworld, the master of the hell, the judge of the dead souls. His head with bull horns is crowned with five skulls. In his right hand Choydzhil holds a lasso with a ring and an iron hook for catching sinful souls and restraining the disobedient; in his left, he holds a skeleton-shaped baton. The actor playing Choydzhil waved the baton from side to side, driving demons away. Sometimes the underworld king would appear with a mirror reflecting all sinful deeds of people.

The second group of the tsam characters are zoomorphic creatures. Those are masks of various animals and birds: Dzharok (Kre), Makha, Shobe, etc. They are believed to have been adopted into Buddhist mythology and ritual practice from the pre-Buddhist Tibetan religion and local shamanistic cults.

The masks of Makha and Shobe are crowned with deer and bull horns. According to B.P. Sal'mont, the eurhythmies of these characters included some abrupt, fast and sudden moves, they jumped around "like chamois". In the final of the dance, Makha and Shobe would face each other and lock their horns. The khokhimai, the masters of cemeteries (wearing human skull-like masks) would approach the zoomorphic animals and stop their fight.

In the opinion of B.P. Sal'mont, Dzharok (Kre) is the least remarkable, a discreet "but highly expressive figure, depicting the enemy of the faith" (Sal'mont, 1928: 192). The costume of Dzharok reminded of a raven. The actor wore tight black clothes, with "something like a short skirt, looking like some feathers" around his waist (Sal'mont, 1928: 192). The bird mask with a red beak was also painted black. The researcher emphasizes that this role ("a shameful one") was never played by a lama. They would never choose to play an enemy of the faith. Traditionally, a poor man was hired for the role.

The third group includes human characters: Geser Bogdo Khan, a national epos hero, 22 shanaks (the supervisor lamas), Khoshin Khan and his sons.

A special part in the mystery play was played by the favourite of the public, Sagaan Ubuguun 
(Tsagan Ubugun - The White Old Man), the deity of fertility and longevity, the master of the territory, the protector of herds and pastures, the god of wild animals. The image of the White Old Man is a collective one, originating from the shamanistic religious tradition of the Turkic and Mongolian peoples. It is not a coincidence that the Mongolian word ebugen is translated as the "ancestor of the tribe". The lama playing this role of the kind and wise old man wore a mask with a long grey beard and thick white eyebrows. During the shanaks' dance, Sagaan Ubuguun entertained the public creating some comic situations: the old man collected money, begged for khadak, sweets, sniffed tobacco and burst into sneezing.

The tsam masks could come out one by one or in pairs, sometimes in groups. It is important to remark that the gestures and moves of the actors were adopted from the cult visual arts and reproduced the canonical postures of the Lamaism deities. The entrance of almost all of the tsam characters was announced by two ganlins, the cult wind instruments made of human shinbone. The researchers state that the instrument is of Ancient Tibetan origin (Dashieva, 2005). In tantric rituals, the ganlin sound called for sinister gods and created the atmosphere of suspense. The ministers of religion played ganlins decorated with long khadyks. During performance, the musicians did rotating moves with their instruments.

B.P. Sal'mont remarked, that before the dance of Makha and Shobe, after the ganlin signals were over, the sounds of reed instrument called bishkhur followed. The melody was repeated with copper plates called dudarmy, "as though sketching a nervous pattern over the merciless statement of the new god's arrival at the temple threshold: go and meet him!" (Sal'mont, 1928: 194).

It is well-known that in Hambin temple of Buryatia the final dance was the dance of dokshits around the Linka. Then the Linka would be ritually cut into pieces. As V.Ts. Naidakova remarks, during the dokshits' dance the ministers of religion carried the Sor outside the monastery premises to burn it on a bonfire (Naidakova, 1997). The final part of the mystery play is described in more details by B.P. Sal'mont. Approximately one kilometre away from the temple, a hay hut (obokhey) was made. Two lamas with tied mouths carried the Sor out. The symbolic threeheaded pyramid was accompanied by the actor playing Choydzhil, supported by the lamas by the hands. Then all the tsam characters would leave the temple and go out into the field one by one. They sat down in two lines, waiting for the other participants of the ceremony: the choir, the orchestra and the leading lamas. The lamas "took some firebrands and set the obokhey on fire $<\ldots>$. The Sor was bent down and thrown into the fire" (Sal'mont, 1928: 208). At this moment of climax, the huge brass elephant trunk-shaped instrument ukher-bure made a powerful, shrieking sound, and the khengerege drums played tremolo. Then the parade would return to the temple premises. At the end of the tsam, all the characters of the play performed a common dance, at the end of which the dokshits and then the shanaks would leave the stage and hide in the temple.

The concept of tsam is presentation of sinister protectors of Buddhism and their fight for the faith. The colourful performance was played for all people present, but nevertheless, tsam is first of all a mystery play and a religious ritual. The purpose of the sacred deed is not only to teach the audience, reminding them of the frailty of life and the mysterious spirits, protecting Buddhism and sometimes being hostile, and also to feel the mystical union of the people with those spirits.

Tsam researchers believe that its roots are ancient, going back to the pre-Buddhist times. The dance mystery play genesis is still understudied. 
The only known fact is that it is much older than Lamaism it is normally associated with, and that tsam masks' prototypes should be looked for among the shamanist spirits, ancestor spirits or even the hunting cult.

One of the most important traits of folklore is its inclusiveness, i.e. the involvement of the folklore culture and its separate components into the ethnos life. One of the indicators of such inclusiveness is the fact that various folklore elements, sustainable as a national tradition, still exist today. Being included not only in the everyday life and industrial practice of people, they play an essential role in the development and evolution of the professional musical and choreographic art of Buryatia.

\section{References}

Avdeev, A. (1959). Proiskhozhdenie teatra. Elementy teatra v pervobytnoobshchinnom stroe [The origin of the theatre. Theatrical elements of the primitive community]. Moscow-Leningrad, $267 \mathrm{p}$.

Berlinskii, P. (1931). Perspektivy muzykovedcheskoy raboty i muzykal'nogo stroitel'stva v BuriatMongolii [The prospects of musicological work and musical development in Buryat-Mongolia]. Verkhneudinsk, $44 \mathrm{p}$.

Buksikova, O. (2009). Ritual 'nye tantsy narodov Vostochnoy Sibiri [Ritual dances of the East Siberian peoples]. In Voprosy kul turologii [Culturology issues], (9), 49-52.

Dashieva, L. (2005). Traditsionnaia muzykal'naia kul'tura buriat: uchebno-metodicheskoe posobie [The Buryat traditional musical culture: textbook]. Ulan-Ude, $188 \mathrm{p}$.

Dugarov, D. (1991). Istoricheskie korni belogo shamanstva (na materiale obriadovogo fol "klora buriat) [The white shamanism's historical roots (based on of the Buryat ritual folklore)]. Moscow, $300 \mathrm{p}$.

Dugarov, D., Kunitsyn, O. (1997). Buriaty [The Buryats]. In Musykal'naia kul'tura Sibiri: v 3 t. T. 1. Traditsionnaia kul'tura narodov Sibiri. Kn. 1. Traditsionnaia kul'tura korennykh narodov Sibiri [Musical culture of Siberian peoples: in 3 v. V.1. The traditional culture of Siberian native peoples]. Novosibirsk, 366-404.

Gerasimova, I. (1988). Filosofskoe ponimanie tantsa [Philosophic understanding of the dance]. In Voprosy filosofii [Philosophy issues], (4), 50-63.

Gergesova, T. (1974). Buriatskie narodnye tantsy [Buryat folk dances]. Ulan-Ude, 88 p.

Ides, I., Brand, A. (1967). Zapiski o russkom posol'stve v Kitae (1692-1695). Vstupit. stat'ia, per. i komment. M. Kazanina [Notes on the Russian embassy in China (1692-1695). Introduction, transl. and commented by M. Kazanin]. Moscow, 404 p.

Inkizhinov, V. (1929). Problemy buriat-mongol'skogo teatra [The problems of Buryat-Mongolian theatre]. In Zhizn'Buriatii [The life of Buryatia], (3/4), 48-59.

Kolpetskaia, O. (2011). Buddiyskaia tantseval'naia misteriia Tsam: po materialam etnograficheskogo issledovaniia B.P. Sal'monta [Buddhist Tsam dance mystery: after ethnographic materials by B.P. Sal'mont]. In Muzykal'naia zhizn' [Musical life], (1), 28-29.

Manzhigeev, I. (1985). Buriatskiy yokhor [The Buryat yokhor]. Ulan-Ude, 65 p.

Mikhailov, T. (1987). Buriatskii shamanism. Istoriia. Struktura. Sotsial 'nye funktsii [The Buryat shamanism. History. Structure. Social functions]. Novosibirsk, 288 p.

Naidakova, V. (1997) Buddiyskaia misteriia Tsam v Buriatii [The Buddhist Tsam mystery in Buryatia]. Ulan-Ude, 40 p.

Naidakova, V. (1985). Narodnoe dramaticheskoe tvorchestvo buriat [The Buryats' folk dramatic art]. In Fol 'klornyi teatr narodov SSSR [The USSR peoples' folk theatre]. Moscow, 199-216. 
Nikolaeva, D. (1998). O funktsiiakh yokhora v traditsionnykh obriadakh buriat [On the functions of yokhor in the Buryats' traditional rituals]. In Traditsionnyy fol 'klor v polietnicheskikh stranakh: materialy mezhdunarodnogo nauchnogo simpoziuma "Baikal'skie vstrechi» [Traditional folklore in polyethnic countries: proceedings of "Baikal Meetings" international scientific symposium]. UlanUde, 64-66.

Okladnikov, A., Zaporozhskaia, V. (1970) Petroglify Zabaikal'ia [Transbaikalian petroglyphs]. Leningrad, $264 \mathrm{p}$.

Romm, V (1998). Tysiacheletiia klassicheskogo tantsa [Millenniums of classical dance]. Novosibirsk, $160 \mathrm{p}$.

Sal'mont, B. (1928). Materialy k izucheniiu buriat-mongol 'skogo iskusstva (pesni, muzyka, tantsy). Rukopis' [The materials for studying the Buryat-Mongolian arts: songs, music, dances. Manuscript]. TSVRK IMBT SO RAN. Inv. № 364. Verkhneudinsk, 229 p.

Tokarev, S. (1990). Rannie formy religii [The early forms of religion]. Moscow, $622 \mathrm{p}$.

Tugutov, I. (1989). Igry v obshchestvennoy zhizni buriat [Games in the Buryats'social life]. UlanUde, $164 \mathrm{p}$.

Shagdaron, S.-D., Ochirov, B.-D. (1909). Igry i uveseleniia aginskikh buriat [The Aga Buryats' games and entertainments]. In Sbornik $v$ chest ${ }^{\prime}$ 70-letiia G.N. Potanina [A digest in honour of G. N. Potanin's 70 th anniversary]. St. Petersburg, 465-482.

Zuev, V. (1947). Materialy po etnografii Sibiri XVIII veka (1771-1772) [The materials on the $18^{\text {th }}$ century Siberian ethnography (1771-1772)]. Moscow, 96 p.

\section{Истоки профессионального \\ музыкально-хореографического искусства \\ Бурятии}

О.Ю. Колпецкая

Красноярский государственный институт искусств Россия, 660049, Красноярск, ул. Ленина, 22

Профессиональное музыкально-хореографическое искусство Бурятии уходит корнями в глубокую древность, являясь неразрывно связанным с фольклорной и культовой практикой народа, его мировоззрением. Использование элементов, заимствованных из народных игр, религиозных и бытовых обрядов, позволяет современным постановщикам создавать самобытный танец, придавать ему ярко национальный колорит, черпая в традиционном искусстве народа разнообразные пластические рисунки и фигуры. Многие хореографические узоры являются типичными для старинного бурятского орнамента. Их семантика подчинена структуре начиональной картины мира, связана с шаманистским и буддийским мировидением народа.

Ключевые слова: бурятский фольклор, хореографические традиции, шаманизм, круговой танеи ёхор, буддийская мистерия Цам, инклюзивность.

Научная специальность: 24.00.00 - культурология, 17.00.00-искусствоведение. 